\title{
|ISAl|II Jurnal Sains Materi Indonesia
}

Akreditation No : 36/E/KPT/2019

\section{EFFECT OF TREATMENT SOLUTION ON THE MICRO- STRUCTURE AND MICROHARDNESS OF TERNARY Ni-Al-Nb ALLOY DOPED WITH TITANIUM}

\author{
Hikmat Nugraha ${ }^{1}$, Pradoto Ambardi ${ }^{1}$, Djoko Hadi Prajitno ${ }^{1,2}$ \\ ${ }^{1}$ Department of Metallurgical Engineering, University of Jenderal Achmad Yani Bandung, \\ Bandung 40284,Indonesia \\ ${ }^{2}$ National Nuclear Energy Agency, Bandung 40132,Indonesia \\ E-mail: nugraha.hikmat66@gmail.com
}

Received: 6 July 2020

Revised: 12 October 2020

Accepted: 20 October 2020

\begin{abstract}
EFFECT OF TREATMENT SOLUTION ON THE MICROSTRUCTURE AND MICROHARDNES OF TERNARY Ni-Al-Nb ALLOY DOPED WITH TITANIUM. Nickel-based superalloys have been widely used in various applications, which require high strength at high temperatures. Most types of these superalloys is age-hardenable because they have $\gamma^{\prime}$ particles' chemical composition $\mathrm{Ni}_{3}(\mathrm{Al}, \mathrm{Ti})$ in $\gamma^{\prime}$ phase matrix. This research will be used alloy Ni-Al-Nb added alloying elements Ti. This research was conducted to study the mechanical properties, microstructure conditions in some alloys $\mathrm{Ni}-\mathrm{Al}-\mathrm{Nb}$ added distinction Titanium element $(0,5 \%$ and $1 \% \mathrm{Ti})$ using the method of aging temperature variation performed at a temperature of $650{ }^{\circ} \mathrm{C}, 700{ }^{\circ} \mathrm{C}$ and $750{ }^{\circ} \mathrm{C}$ with a holding time 4 hours and air cooling. Tests were conducted to determine the characterization of the specimen includes testing metallographic optical microscope, Rockwell hardness $\mathrm{C}$ and SEM- EDS,XRD. Results obtained from this research that addition of titanium element affecting the hardness values as well as the results of the cast, solution treatment and aging process results. The $1 \%$ Titanium content can affect the gamma prime coarsening and make the grain on the microstructure result smooth.
\end{abstract}

Keywords: Ni base supperalloy, Ni-Al-Nb, Aging, Effects of Titanium element

\begin{abstract}
ABSTRAK
PENGARUH PERLAKUAN PELARUTAN PADA MIKROSTRUKTUR DAN MICROHARDNES PADUAN TERNER Ni-AI-Nb YANG DI DOPING DENGAN TITANIUM. Superalloy berbasis nikel telah banyak digunakan dalam berbagai aplikasi, dimana membutuhkan kekuatan tinggi pada suhu tinggi. Sebagian besar tipe dari superalloy ini adalah age-hardenable (mampu keras),karena mereka memiliki partikel $\gamma^{\prime}$ dengan komposisi kimia $\mathrm{Ni}_{3}(\mathrm{Al}, \mathrm{Ti})$ dalam matriks fasa $\gamma^{\prime}$. Pada penelitian ini akan digunakan paduan Ni-Al- $\mathrm{Nb}$ yang ditambahkan unsur pemadu Ti. Penelitian ini dilakukan untuk mempelajari sifat mekanik, kondisi struktur mikro pada beberapa paduan $\mathrm{Ni}-\mathrm{Al}-\mathrm{Nb}$ yang ditambahkan perbedaan unsur Titanium $(0,5 \%$ dan $1 \% \mathrm{Ti})$ menggunakan metode variasi temperatur aging yang dilakukan pada temperatur $650{ }^{\circ} \mathrm{C}, 700{ }^{\circ} \mathrm{C}$ and $750{ }^{\circ} \mathrm{C}$ dengan holding time 4 jam serta media pendingin udara. Pengujian yang dilakukan untuk mengetahui karakterisasi spesimen meliputi pengujian metalografi menggunakan mikroskop optik, Rockwel hardness C, dan SEM-EDS, XRD. Hasil yang diperoleh dari penelitian ini yaitu Penambahan unsur Titanium mempengaruhi nilai kekerasan baik setelah hasil proses as cast, solution treatment maupun hasil proses aging. Kandungan Titanium 1\% dapat mempengaruhi coarsening gamma prime dan membuat butir pada hasil struktur mikro menjadi halus.
\end{abstract}

Kata kunci: Ni base supperalloy, Aging, Pengaruh unsur Titanium 


\section{INTRODUCTION}

Superalloys are heat-resistant alloys of nickelbased, iron-nickel, and cobalt-nickel which showed a good combination of mechanical strength and resistance to surface degradation. High temperature strength at all base superalloys matrix based on the principle of facecentered cubic (fcc) combined with precipitation strengthening and solid-solution hardening. [1].

In the nickel-base alloy, intermetallic $\gamma^{\prime}\left(\mathrm{Ni}_{3} \mathrm{Al}, \mathrm{Ti}\right)$ generally has the properties to strengthen, while the alloy nickel, cobalt, and iron depend on strengthening on solid solution strengthening of the matrix fcc $(\gamma)$. Ironbased superalloys and nickel-iron can also be grown in the presence of $\gamma^{6}$, the strengthening of the second phase of a $\boldsymbol{\gamma}^{\prime}\left(\mathrm{Ni}_{3} \mathrm{Nb}\right)$ intermetallic and maybe $\boldsymbol{\eta}\left(\mathrm{Ni}_{3} \mathrm{Ti}\right)$. Cobaltbase superalloys can develop some boosters precipitation of carbides $\left(\mathrm{Cr}_{7} \mathrm{C}_{3}, \mathrm{M}_{23} \mathrm{C}_{6}\right)$, but there is no strengthening of intermetallic phases of the same with the strengthening of the nickel-based alloys have been found in cobalt-base superalloys. [3]. Nickel-based superalloys have been widely used in various applications, which require high strength at high temperatures. Most types of these superalloys is age-hardenable because they have $\gamma$ particles' chemical composition $\mathrm{Ni}_{3}(\mathrm{Al}, \mathrm{Ti})$ in $\gamma$-phase matrix. Superalloy properties depend on the size and distribution of precipitates $\gamma^{6}[1-3]$.

The investigations of intermetallic alloys is generally concentrated on the system $\mathrm{Fe}-\mathrm{Al}$, Ti-Al and Ni$\mathrm{Al}$. In addition, $\mathrm{Ni}_{3} \mathrm{Al}$-based alloys have been given the attention for excellence in physical and mechanical properties, such as low density, high temperature strength and excellent corrosion resistance. Superalloy nickel involving elements in significant amounts, Characteristic of each of the elements alloying and its effect on phase stability depends on its position in the periodic table of elements such as Ni, Co, Fe, Cr, Ru, Mo, Rh and $\mathrm{W}$ tend to be partitioned in the austenite phase $(\gamma)$ and stabilize this phase. [4]. Investigations on intermetallic alloys generally concentrated on the system $\mathrm{Fe}-\mathrm{Al}, \mathrm{Ti}-\mathrm{Al}$ and Ni$\mathrm{Al}$. In addition, $\mathrm{Ni}_{3} \mathrm{Al}$ - based alloys have been given the attention for excellence in physical and mechanical properties, such as low density, high temperature strength and excellent corrosion resistance [5-8]. These elements have a radius not much different from the $\mathrm{Ni}$ and elements such as $\mathrm{Al}, \mathrm{Ti}, \mathrm{Nb}$ and $\mathrm{Ta}$ which have a radius of atoms are larger and tend to form ordered as phase $\left(\gamma^{\circ}\right)$ $\mathrm{Ni}_{3}(\mathrm{Al}, \mathrm{Ti}, \mathrm{Ta})$ as the main amplifier particles. While elements such as B, $\mathrm{Zr}$ and $\mathrm{C}$ is the third group of inclined elements segregated to the grain boundaries of matriknya phase $(\gamma)$ [9]. Phases of existing fixed react and interact. Phases that can appear based on the binary phase diagram of $\mathrm{Ni}-\mathrm{Al}$ is the matrix $\gamma$, precipitated $\gamma^{\mathbf{c}}$ and carbides [10].

The addition of alloying elements (Al and Ti) resulting in coherent phase $\gamma^{\prime}[\mathrm{Ni}(\mathrm{Al}, \mathrm{Ti})]$ which can provide a strengthening effect. But the ã-phase and phase $\gamma^{\prime}$ has a different lattice parameter. This difference produces a coherent strain that can hinder the movement of dislocations resulting in hardening precipitates. Elements such as chromium and aluminum are added, aims to improve protection against hot corrosion and high temperature oxidation. [11].

The purpose of this study was to test the mechanical properties, of hardness and mikrostructure the ternary alloy Ni-Al-Nb when added with titanium at different concentrations under conditions of solution treatment and aging $1200^{\circ} \mathrm{C}$.

\section{MATERIALS AND METHODS}

\section{Specimen Preparation}

The chemical composition of the alloy used in this study is the system of Ni-Al-Nb, Ni-Al- $\mathrm{Nb}-\mathrm{X} \mathrm{Ti}(\mathrm{x}=$ $0.5 \%$ and $1 \%$ ) is made of square nickel, aluminum, niobium and titanium with a purity of $99+\%$. The process of weighing each ingredient according to the material balance as shown in Table 1.

\section{Aging Testing}

Alloys are processed using single arc furnace melting furnace using hearth furnace copper crucible by flowing water as a coolant conducted in the atmosphere of argon gas with high purity and used as an electrode

Table 1. Chemical Composition (wt\%)

\begin{tabular}{l|c|c|c|c}
\hline \multirow{2}{*}{ specimens } & \multicolumn{3}{|c}{ \% weight } & $\mathrm{Ti}$ \\
\cline { 2 - 5 } & $\mathrm{Ni}$ & $\mathrm{Al}$ & $\mathrm{Nb}$ & - \\
\hline Alloy-1 (Ni-Al-Nb) & 76.05 & 6.65 & 17.25 & 1 \\
\hline Alloy-2 (Ni-Al-Nb-0.5\% Ti) & 75.65 & 6.6 & 16.7 & 2 \\
\hline Alloy-3 (Ni-Al-Nb-1\% Ti) & 75.3 & 6.55 & 17.05 & \\
\hline
\end{tabular}


in which tungsten if the tungsten interact with the surface of the material will produce an electric arc (arc).

After aging testing the specimens were observed with an Olympus BX60M optical microscope for testing metallography using epoxy resin and then polished mechanically with grid sandpaper 80 to 2000 and etching using aqua regia solution of $20 \mathrm{ml}$ of $\mathrm{HCl}$ and $60 \mathrm{~mL}$ $\mathrm{HNO}_{3}$. Hardness measurement specimens was performed by Krisbow Rockwell Hardness Tester with C-Scale. Analysis of X-ray diffraction (XRD) is used for phase identification and characterization of the specimen after the aging process using PAN alytical / X'Pert PRO PW3040 / x0. The specimens were analyzed by SEM using a Hitachi SU3500 and EDS using Ametek Apollo XL.

\section{RESULTS AND DISCUSSION}

\section{Microstructure alloys as solution treatment}

In Figure 1 shows the results of the microstructure of the alloy after solution treatment of the specimen $\mathrm{Ni}$ $\mathrm{Al}-\mathrm{Nb}$ with and without doping by Ti. The solution treatment process is carried out to influence the formation

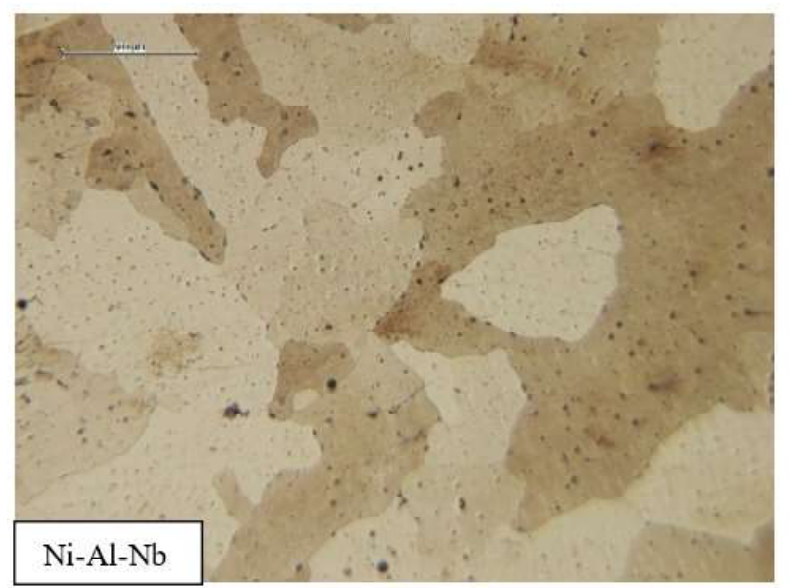

of the microstructure morphology of the three alloys. After of the specimen $\mathrm{Ni}-\mathrm{Al}-\mathrm{Nb}$ with and without doping by $\mathrm{Ti}$ reheating at a temperature $1200^{\circ} \mathrm{C}$ for 2 hours, followed by rapid cooling using water media, it is shown that the microstructure morphology and grain size are different form microstructure. When the grain is enlarged, diffusion phenomena also occur which also arise due to temperature variables, where during the diffusion the atoms will tend to move to find equilibrium which is to look for areas with lower chemical potential, along with the heating time carried out during the solution process the treatment of the diffusion phenomenon continues, until after reaching 2 hours, rapid cooling is done with the water medium, the rapid cooling, affects several things, including, the unit cell that occurs will become more tightly the distance between cells which causes mechanical properties also increase, the emergence of carbides trapped in the phase growth that occurs. [12].

The alloys of the specimen $\mathrm{Ni}-\mathrm{Al}-\mathrm{Nb}$ with and without doping by $\mathrm{Ti}$ after the solution treatment process will form the phase $\gamma^{`}$ as in the arrow indicated. The Ni element will form $\mathrm{Ni}_{3} \mathrm{Al}, \mathrm{Ni}_{3} \mathrm{Nb}$ and $\mathrm{Ni}_{3} \mathrm{Ti}$

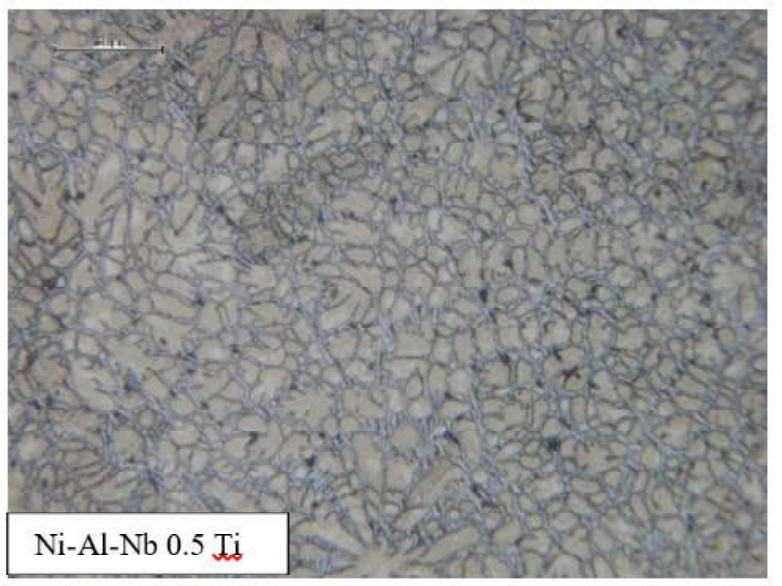

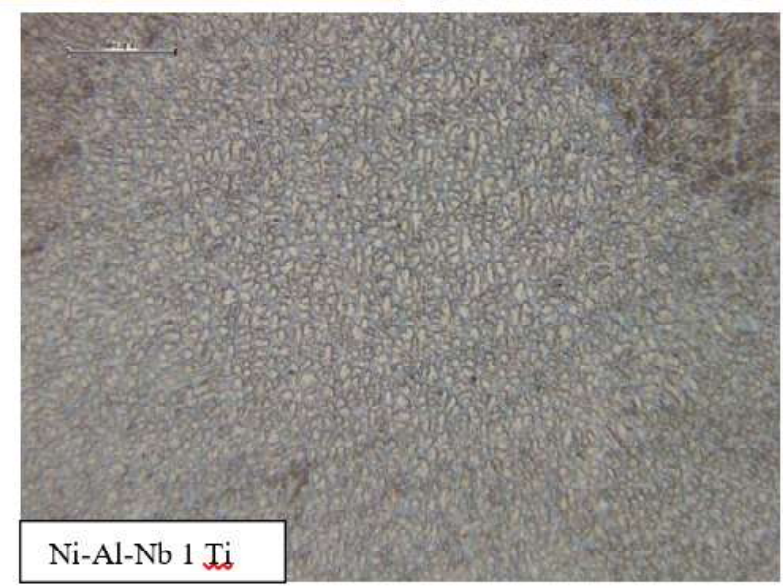

Figure 1. Microstructure 3 different alloys Ni-Al-Nb, Ni-Al-Nb-0.5\% Ti, Ni-Al-Nb-1\% Ti after solution treatment at $1200{ }^{\circ} \mathrm{C}$ for 2 hours $100 \mathrm{x}$ 

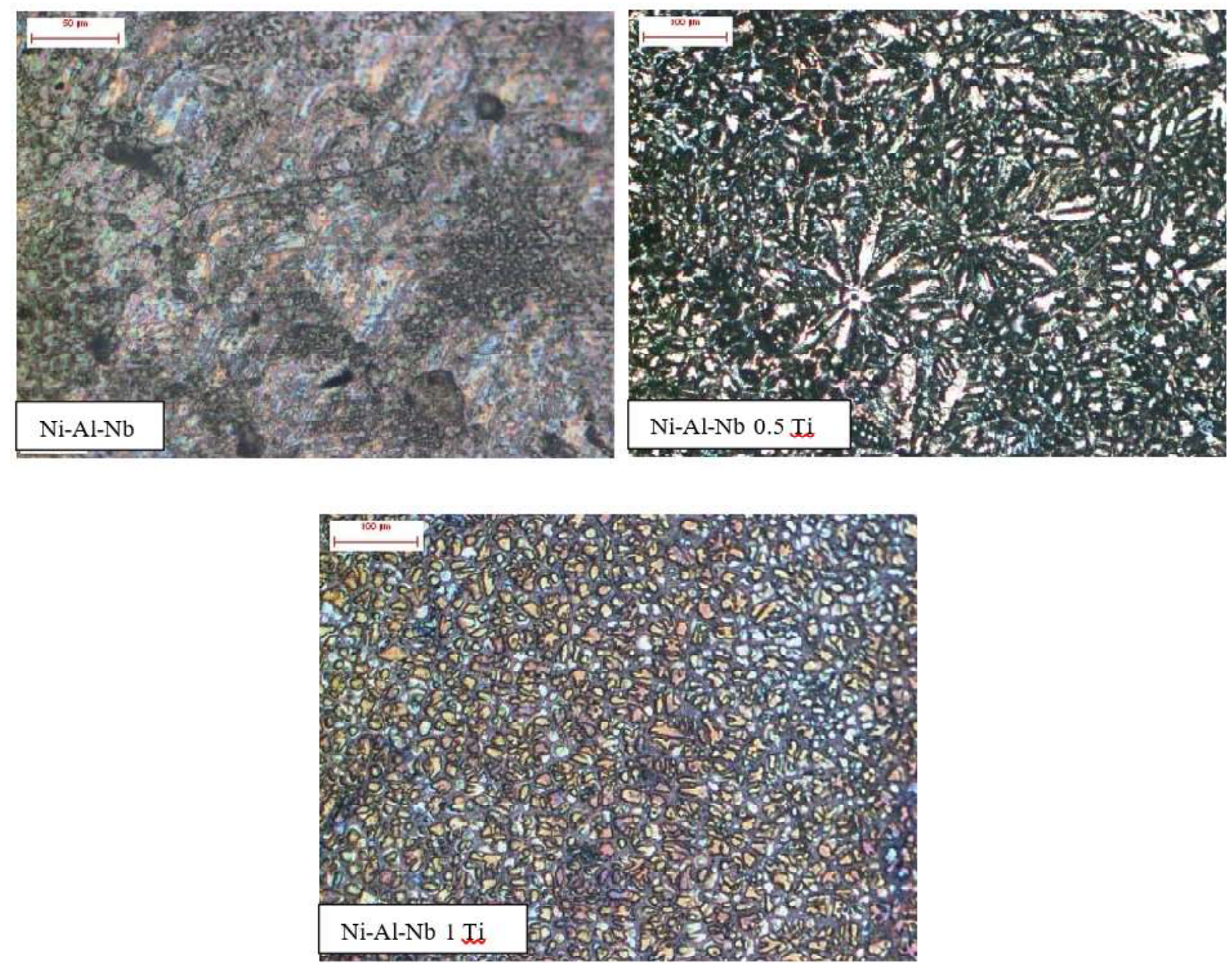

Figure 2. Microstructure 3 different alloys $\mathrm{Ni}-\mathrm{Al}-\mathrm{Nb}$, Ni-Al-Nb-0.5\% Ti, Ni-Al-Nb-1\% Ti after aging at $750{ }^{\circ} \mathrm{C}$ for 4 hours $100 \mathrm{x}$

precipitates after the solution treatment process which will affect the mechanical properties of the alloy. The addition of $\mathrm{Ti}$ to the alloy will cause the nucleating agent mechanism to refine the grain as can be seen in Figure 1.

\section{Microstructure as aging $750{ }^{\circ} \mathrm{C}$}

In Figure 2 shows the microstructure of aging as alloy at $750^{\circ} \mathrm{C}$ temperature for 4 hours with air cooling media. Formed mechanism that forms the sludge precipitates gamma prime phase $\mathrm{Ni}_{3} \mathrm{Al}, \mathrm{Ni}_{3} \mathrm{Nb}$ and $\mathrm{Ni}_{3} \mathrm{Ti}$ on the alloy.The presence of intermetallic phase serves as the main amplifier on a Ni-base superalloys, especially on the resistance to high temperatures. There is precipitated phase $\gamma$ ' $\mathrm{Ni}_{3}(\mathrm{Al}, \mathrm{Ti})$ that has been distributed into the matrix is capable of inhibiting movement of dislocations, which is responsible for increasing the yield strength. [3].

Differences solutioan treatment and aging process that is on the grain size distribution, where the addition of Ti relatively smaller grain size and grain coarsening inhibiting gamma prime. This affects the mechanical properties, the greater the temperature of aging the resulting mechanical properties will affect the hardness value. Influence the addition of $\mathrm{Ti}$ the specimen causes the sediment grains grow evenly in all areas and dissolve in the alloy.

\section{Hardness of alloy}

In Figure 3 shows that the addition of $\mathrm{Ti}$ will increase alloy hardness in the process of solution treatment. Niobium and Titanium strengthening precipitate $\gamma^{6}$ to replace $\mathrm{Al}$ in $\mathrm{Ni}_{3} \mathrm{Al}$ with precipitation hardening mechanism. Precipitation hardening occurs because through the process of heating and exceeds the solubility limit of $\mathrm{Al}, \mathrm{Nb}$ and $\mathrm{Ti}$ in nickel and produces a phase $\mathrm{Ni}_{3} \mathrm{Al}\left(\gamma^{\prime}\right), \mathrm{Ni}_{3} \mathrm{Nb}\left(\gamma^{\prime}\right.$ ') and phase $\mathrm{Ni}_{3} \mathrm{Ti}$.

Interest aging process carried out to obtain an effective arrangement or uneven reinforcement in order to obtain maximum hardness or strength and form a substrate of microstructure or fine grain.At $750^{\circ} \mathrm{C}$ aging 
Effect of Treatment Solution on The Microstructure and Microhardnes Of Ternary Ni-Al-Nb Alloy Doped With Titanium (Hikmat Nugraha)

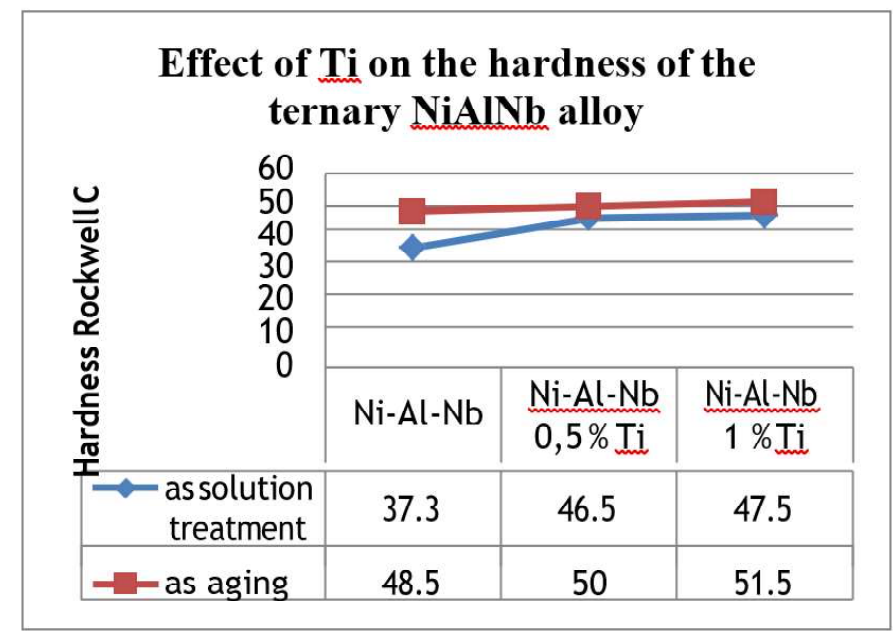

Figure 3. Alloy hardness $\mathrm{Ni}-\mathrm{Al}-\mathrm{Nb}, \mathrm{Ni}-\mathrm{Al}-\mathrm{Nb}-0.5 \% \mathrm{Ti}, \mathrm{Ni}-\mathrm{Al}-\mathrm{Nb}-$ $1 \% \mathrm{Ti}$ after the solution treatment and the aging process.

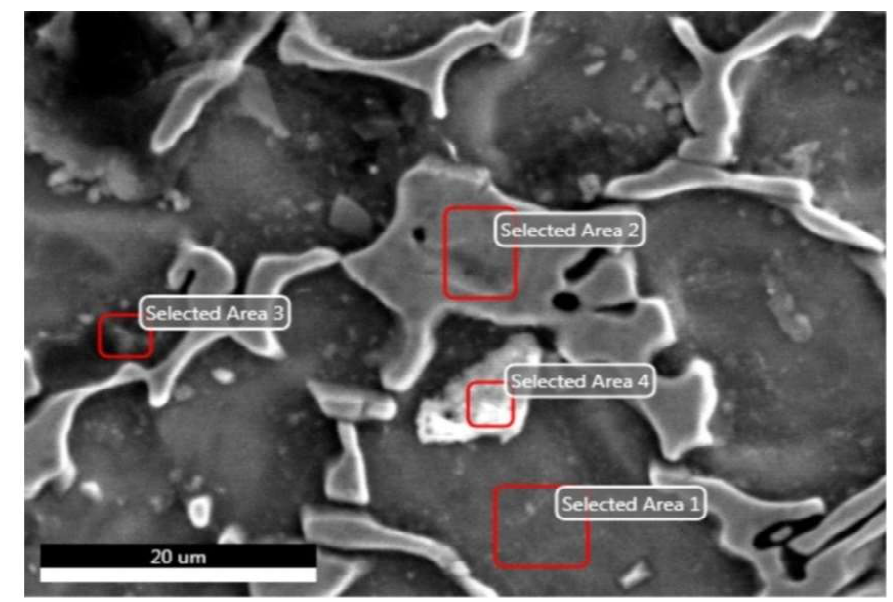

Figure 4. SEM alloys Ni-Al-Nb-Ti $1 \%$ after Aging $750{ }^{\circ} \mathrm{C}$ SEM

get an increase in hardness, because at a temperature of about $750{ }^{\circ} \mathrm{C}$ and $800{ }^{\circ} \mathrm{C}$ is the temperature stability gamma + gamma prime temperature equilibrium which makes its constancy increase as the number of gamma prime particles is formed until its peak strength is reached [1-3].

\section{SEM alloy Ni-Al-Nb-Ti 1\%}

In Figure 4 the samples were tested for SEM and EDS, are Ni-Al-Nb $1 \%$ Ti aging $750{ }^{\circ} \mathrm{C}$ with a holding time of 4 hours. The results of SEM testing can be seen in Figure 4 which for the dark areas on the samples Ni-Al-

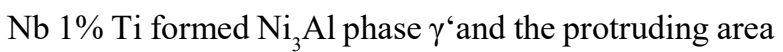
formed $\mathrm{Ni}_{3} \mathrm{Nb}$ phase $\gamma$ ' " as well as the light formed $\mathrm{Ni} \gamma$ phase and phase distribution $\mathrm{Ni}_{3} \mathrm{Ti} \gamma$ ' that dissolve completely in the samples of Ni-Al. Type of reinforcement at each compound is for $\mathrm{Ni}$ based solid solution matrix, as
Table 2. Chemical composition of alloys $\mathrm{Ni}-\mathrm{Al}-\mathrm{Nb}$ $1 \% \mathrm{Ti}$ aging $750{ }^{\circ} \mathrm{C}(\mathrm{wt} \%)$

\begin{tabular}{rcccc}
\hline $\begin{array}{c}\text { Elements } \\
(\mathbf{W t} \%)\end{array}$ & $\mathbf{1}$ & $\mathbf{2}$ & $\mathbf{3}$ & $\mathbf{4}$ \\
\hline $\mathbf{A l}$ & 7.85 & 0.00 & 9.41 & 1.13 \\
\hline $\mathbf{N b}$ & 13.20 & 26.97 & 16.91 & 3.37 \\
\hline $\mathbf{N i}$ & 78.95 & 73.03 & 73.69 & 95.50 \\
\hline $\mathbf{T i}$ & 0.91 & 0.91 & 0.91 & 0.91 \\
\hline
\end{tabular}

aging compounds that occur are strengthening precipitation hardening.

Because during the aging process elements of $\mathrm{Al}, \mathrm{Nb}$ and Ti will seek stability or purity so as to form a bond precipitates. EDS testing result can be seen in table 2 with a few selected area and can be calculated and plotted on a ternary diagram to determine the phase contained in the selected areas. 


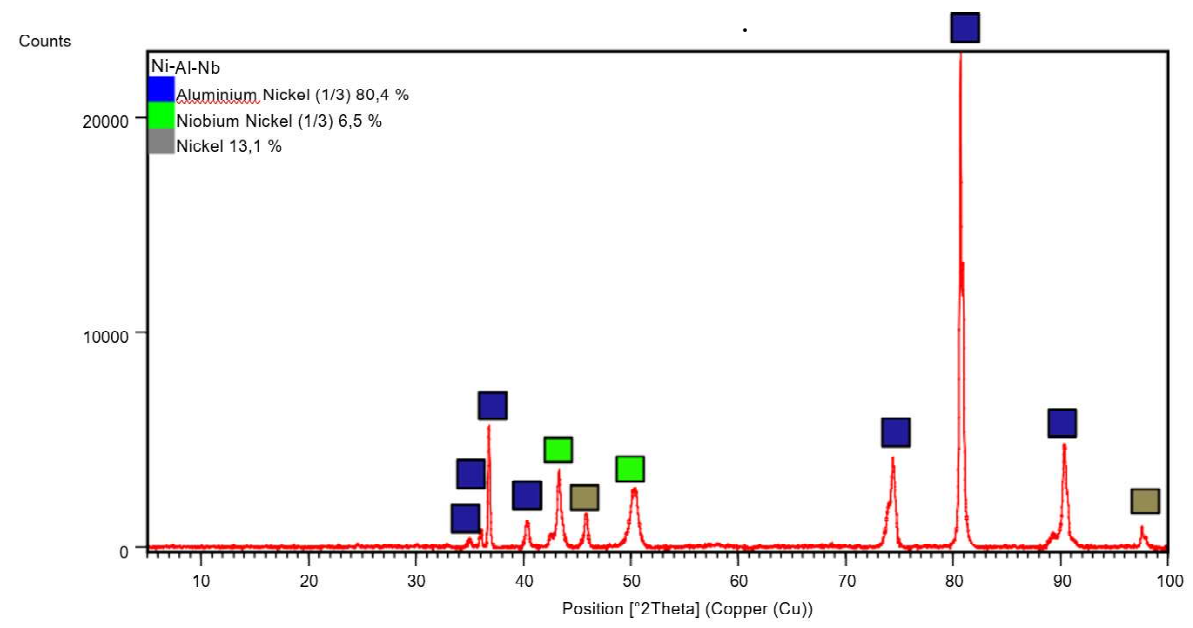

(a)

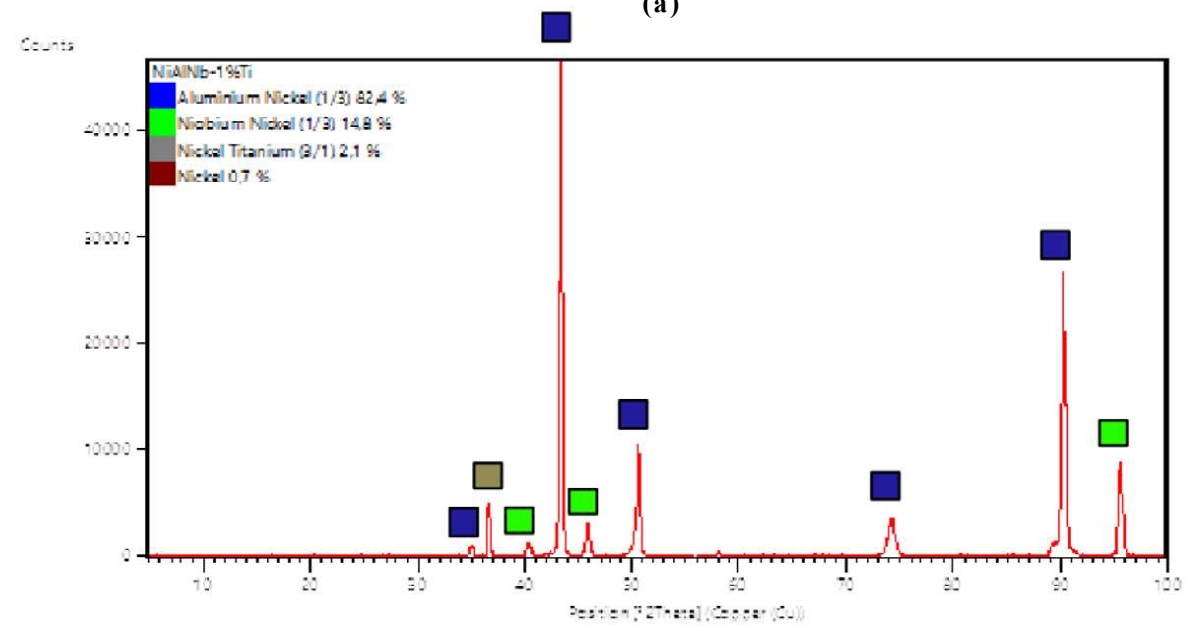

(b)

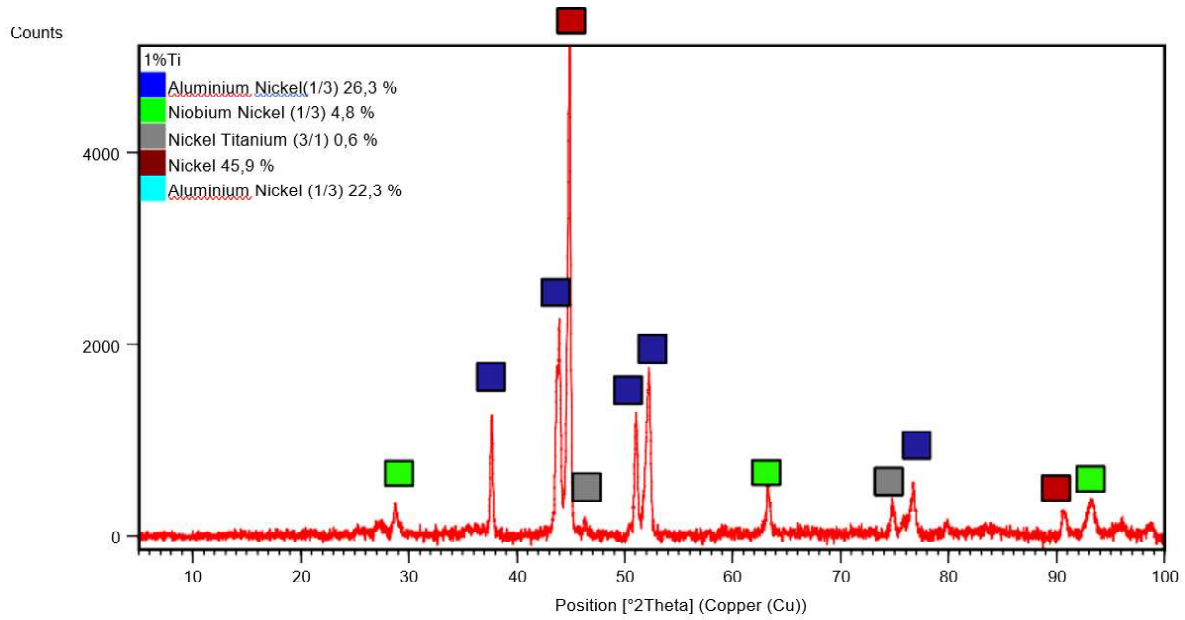

(c)

Figure 5. Results of XRD Patterns Alloys Ni-Al-Nb (a) and Ni-Al-Nb $1 \% \mathrm{Ti}$ (b) before aging and After aging $750{ }^{\circ} \mathrm{C} \mathrm{Ni-Al-Nb} 1 \% \mathrm{Ti}(\mathrm{C})$

\section{X-Ray Diffraction}

Figure 5 shows the $\mathrm{X}$-ray diffraction pattern for a $\mathrm{Ni}-\mathrm{Al}-\mathrm{Nb}$ and Ni-Al-Nb 1\% Ti before aging (a) and (b) and $\mathrm{Ni}-\mathrm{Al}-\mathrm{Nb} 1 \% \mathrm{Ti}$ after aging at $750{ }^{\circ} \mathrm{C}$ (c). In Figure $5 \mathrm{a}$, it can be seen that the diffraction pattern indicate the presence of $\gamma$-Ni phase, $\mathrm{Ni}_{3} \mathrm{Al}\left(\gamma^{\prime}\right)$ and $\mathrm{Ni}_{3} \mathrm{Nb}\left(\gamma^{\prime}\right.$ ') and in Figure $5 \mathrm{~b}$ are $\mathrm{Ni}_{3}$ Ti phase $(\delta)$ before aging. After aging, in Figure $5 \mathrm{c}$ where the result as aging phase highest in $\mathrm{Ni} \gamma$ and phase $\mathrm{Ni}_{3} \mathrm{Ti}$ increases, the addition of $\mathrm{Ti}$ in $\mathrm{Ni}$ -

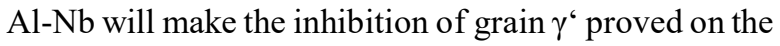


Effect of Treatment Solution on The Microstructure and Microhardnes Of Ternary Ni-Al-Nb Alloy Doped With Titanium (Hikmat Nugraha)

microstructure, the higher the temperature of aging the distribution of grain will the closer and the shape will be uniform.

\section{CONCLUSION}

Effect of solution treatment and aging tests on the alloy $\mathrm{Ni}-\mathrm{Al}-\mathrm{Nb}$ with Ti doping on aging $750^{\circ} \mathrm{C}$. alloy mechanical properties, especially hardness will increase with the addition of doping Ti and Ti content. Violence aging will increase compared to violent treatment solution due to temperature aging process will make the grain will be uneven and Titanium content of $1 \%$ can affect the gamma prime coarsening and make the grain on the results of micro structure becomes smoother and increase the value of violence. Phase alloy is formed on $\mathrm{Ni}_{3} \mathrm{Al}$ phase $\gamma^{\text {', }} \mathrm{Ni}_{3} \mathrm{Nb} \gamma$ ' 'phase $\mathrm{Ni} \gamma$ and $\mathrm{Ni}_{3} \mathrm{Ti} \delta$.

\section{ACKNOWLEDGEMENT}

The authors are grateful to PSTNT-Nuclear Atomic Energy Agency of Bandung for the whole process of research and Metals Laboratory, Faculty of Engineering, University General Achmad Yani for characterization.

\section{REFERENCES}

[1] S. Antonov, M. Detrois, D. Isheim, D.N. Seidman, R.C. Helmink, R. Goetz, E. Sun, S. Tin, "Comparison of Thermodynamic Models and APT Database of Data for Modeling in High Strength $\mathrm{Nb}$ Content of $\gamma-\gamma$ ' Ni-base Superalloys." Materials and Design, vol. 86, pp. 649-655, 2015.

[2] M. Azadi, A. Marbout, S. Safarloo, M. Azadi, M. Shariat, and M.H. Rizi. "Effects of Solutioning and Aging Treatments on Properties of Inconel-713C Nickel-based Superalloys Under Creep Loading." Materials Science and Engineering A, vol. 711, pp. 195-204, 2018.
[3] B.E. Agus. "Innovation and Engineering Materials Superalloys and Development Efforts in Indonesia”2013.

[4] P. Jozwik, W. Polkowski, and Z. Bojar, "Applications of $\mathrm{Ni}_{3} \mathrm{Al}$ Based Alloys Intermetallic-Current Stage and Potential Perceptivities." Materials (Basel), vol. 8, pp. 2357-2568, 2015.

[5] S. Jiang, D. Sun, Y. Zhang, and B. Yan. "Influence of Heat Treatment on Microstructures and Mechanical Properties of Nickel-Based Alloy NiCuCrMoTiAlNb" Metals (Basel), vol. 8, no. 4, p. 217, 2018.

[6] K. Aoki and O. Izumi. "Improvement in Room Temperature Ductility of the intermetallic compound Ni3Al by Ternary Trace Element Addition." Journal of The Japan Institute of Metals, vol. 43, no. 4, pp. 358-359, 1979.

[7] N.R. Council and Publication Team. Intermetallic Alloy Development: A Program Evaluation, Washington DC: The National Research Council, 1997, pp. 10-31.

[8] N.S. Stoloff, V.K. Sikka, Physical Metallurgy and Processing of Intermetallic Compounds, US: Springer, 1996.

[9] G.R. Thellaputta, P.S. Chandra, and C.S.P. Rao. "Machinability of Nickel Based Superalloys: A Review.” In Mater. Today Proc., 2017, vol. 4, no. 2, pp. 3712-3721.

[10] Z. Wen, Y. Zhao, H. Hou, N. Wang, L. Fu, and P. Han. "A first-principles study on the interfacial properties of $\mathrm{Ni}(001) / \mathrm{Ni} 3 \mathrm{Nb}(001)$." Transactions of Nonferrous Metals Society of China, vol. 24, pp. 1500-1505, May 2014

[11] ASMH Committee. "Metals Handbook: Heat treating." ASM International, 1981.

[12] L. Sheng, Y. Yang, and T. Xi. "Effect of heat treatment on morphology evolution of $\mathrm{Ti}_{2} \mathrm{Ni}$ phase in Ti-Ni-Al-Zr alloy”. In IOP Conf. Ser. Mater. Sci. Eng., 2018, vol.322, no. 2. 
